\title{
Representasi Perempuan Pekerja Migran menurut Laki-laki di Kota Palembang
}

\author{
Armansyah dan Mirna Taufik \\ Program Studi Pendidikan Geografi, Universitas PGRI, Palembang \\ Korespondensi: Armansyah (e-mail: armagedone77@yahoo.com)
}

\begin{abstract}
Abstrak
Partisipasi perempuan dalam lapangan kerja terus meningkat. Mereka rela melakukan migrasi ke tempat yang jauh dari keluarga untuk mencari pekerjaan. Dulu perempuan bermigrasi pada jarak yang dekat, tetapi saat ini mereka dapat bermigrasi sampai lintas negara. Penelitian ini bertujuan menjelaskan representasi perempuan pekerja migran menurut laki-laki di Kota Palembang. Metode kualitatif digunakan dalam penelitian ini dengan pengumpulan data melalui observasi, wawancara, dan dokumentasi. Data diperoleh dari wawancara terhadap informan yang dipiilih dengan teknik purposive sampling. Analisis data menggunakan reduction, display, dan conclusion, sedangkan keabsahan data menggunakan derajat credibility melalui tahapan perpanjangan pengamatan, peningkatan ketekunan, dan triangulasi. Hasil penelitian menunjukkan representasi laki-laki di Kota Palembang terhadap perempuan pekerja migran adalah baik. Budaya perempuan bermigrasi dan bekerja dianggap hal yang biasa dan baik pada era modern sekarang ini. Secara umum, perempuan dianggap lebih baik jika bekerja dekat dengan lingkungan keluarga. Namun, jika harus bermigrasi, disarankan keluarga (suami dan anak) hendaknya ikut serta. Sebagian besar informan mendukung pasangannya bekerja dan bermigrasi, serta bentuk dukungan yang diberikan, seperti membantu pekerjaan rumah, mencuci, menyapu, dan mengurus anak.
\end{abstract}

Kata kunci: representasi, perempuan pekerja, migran

\section{Representation of Women Migrant Workers by Men in Palembang City}

\begin{abstract}
Women's participation in employment continues to increase. They are willing to migrate to a place away from the family to work. In the past, women migrated close to their origin, but now they can migrate across the country. This study aims to explain the representation of female migrant workers by men in Palembang City. The method used is qualitative, with data collection through observation, interview and documentation. Data obtained from interviews with selected informants with purposive sampling technique. Data analysis uses reduction, display, and conclution, while data validity uses degrees of credibility through
\end{abstract}


extension stages of observation, increased persistence, and triangulation. The results showed that male representation in Palembang City toward female migrant workers was good. The culture of women migrating and working is considered normal and good in the today's modern era. In general, women are considered to be better working closer to the family's environment. However, if they haves to migrate, it is advisable that their families (husband and child) should accompany them. Most informants support their partners to work and migrat, forms of support are such as asisting the house chores, washing, sweeping, and caring for children.

Keywords: representation, women workers, migrants

\section{Pendahuluan}

Kota Palembang memiliki jumlah penduduk 1.558 .491 jiwa dengan jumlah penduduk laki-laki sebanyak 780.698 jiwa dan penduduk perempuan 777.793 jiwa. Penduduk Kota Palembang dari tahun 2013 ke 2014 berkembang sekitar 1.47 persen (BPS, 2014). Pada 2016 jumlah penduduk Kota Palembang adalah 1.602.100 jiwa, dengan komposisi penduduk laki-laki sebesar 803.00 jiwa $(50,12$ persen) dan penduduk perempuan sebesar 799.100 jiwa $(49,88$ persen) (http://dinkes.palembang.go.id/ tampung/dokumen/dokumen-147-263.pdf). Dengan adanya peningkatan pembangunan di Kota Palembang, kota ini memiliki daya tarik yang besar bagi para migran. Migran adalah individu yang melakukan migrasi dari suatu tempat ke tempat yang lain. Menurut Tarmizi (2013: 1), terdapat tiga variabel yang menentukan tinggi rendahnya pertumbuhan penduduk, yaitu fertilitas, mortalitas, dan migrasi.

Saat ini arus migrasi terjadi semakin cepat. Jarak yang jauh dan waktu tempuh yang lama bukan lagimerupakan masalah bagi penduduk. Hal itu karena semua kendala dapat diatasi dengan kemajuan transportasi baik darat, laut maupun udara. Menurut Lee (1991) dalam Nasution (1999: 109), migrasi dalam arti luas adalah perubahan tempat tinggal secara permanen atau semipermanen. Tidak ada pembatasan, baik pada jarak perpindahan maupun sifatnya, yaitu apakah tindakan itu bersifat sukarela atau terpaksa; serta tidak ada perbedaan antara migrasi dalam negeri dan migrasi ke luar negeri. Pendapat serupa disampaikan oleh Smith dalam Standing (1991: 10) yang menyatakan bahwa migrasi merupakan semua perpindahan ruang fisik, termasuk perubahan tempat tinggal. Dengan meningkatnya arus migrasi akibat dari kemajuan teknologi dan pembangunan, Kota Palembang terus mengalami peningkatan jumlah penduduk. Oleh karenaitu, penyebaran penduduk cenderung ke daerah perkotaan yang memiliki sarana dan prasarana kehidupan yang lengkap. Sementara itu, teori migrasi yang dipakai dalam penelitian ini adalah teori Lee (1996), Todaro (1995), dan Titus (1982) yang menyatakan bahwa motivasi utama untuk berpindah adalah motif ekonomi, yaitu motif yang berkembang karena adanya ketimpangan ekonomi antara berbagai daerah (http://randyibo.blogspot. co.id/2016_01_01_archive.html).

Pelaku migrasi bukan hanya laki-laki, melainkan saat ini telah banyak perempuan yang melakukan migrasi, baik dalam jarak dekat maupun jarak jauh. Berbicara tentang perempuan sebagai pelaku migrasi tentunya sangat erat berkaitan dengan keamanan dan juga pola hidup perempuan yang tinggal 
jauh dari keluarga. Hal yang paling penting adalah faktor keamanan dan pergaulan yang kerap kali dapat mengancam keselamatan perempuan sebagai migran di daerah yang baru. Sama halnya dengan laki-laki, perempuan yang melakukan migrasi juga bertujuan untuk mendapatkan pekerjaan di tempat yang baru.

Tampak adanya peningkatan angka kekerasan terhadap perempuan (KtP) sejak 2010 dan yang tertinggi terjadi antara tahun 2011 sampai tahun 2012 yang mencapai 35 persen. Untuk 2015, jumlah kasus meningkat sebesar 9 persen dari tahun 2014. Angka ini adalah jumlah kasus KtP yang dilaporkan, sedangkan yang tidak dilaporkan mungkin dapat lebih tinggi seperti fenomena gunung es (Komisi Nasional Anti Kekerasan Terhadap Perempuan, 2016: 1). Tingkat kekerasan ini dapat terjadi kepada perempuan yang bermigrasi maupun yang tidak bermigrasi. Namun, perempuan yang bermigrasi akan lebih rentan terkena tindak kekerasan karena jauh dari keluarga. Selain itu, juga penelitian Setiadi membuktikan migrasi perempuan menjadi pendorong perubahan nilai budaya dalam masyarakat tampak cukup dinamis (https://ugm.ac.id/id/ berita/2649migrasi. perempuan.mendorong. perubahan.nilai.budaya). Perubahan tersebut tampak pada berkurangnya peran pasangan (suami) dalam kehidupan berumah tangga, perempuan menjadi tulang punggung keluarga, serta meningkatnya peran dan rasa percaya diri perempuan dalam kehidupan bermasyarakat.

Menyikapi hal tersebut, tampak adanya perubahan budaya pada fungsi dan peran perempuan. Salah satu penyebabnya adalah meningkatnya karakteristik demografi yang dimiliki oleh perempuan pekerja, seperti pendidikan dan keterampilan (Armansyah \& Kiki Aryaningrum, 2017). Perempuan yang memiliki pendidikan dan keterampilan yang baik akan lebih banyak memilih untuk bekerja dan melakukan migrasi. Perubahan ini tentunya akan mendapatkan respons dari berbagai lapisan masyarakat, khususnya kaum laki-laki. Untuk itu, peneliti mencoba melakukan kajian tentang representasi. Representasi adalah cara untuk membentuk pengetahuan yang dimungkinkan oleh otak untuk memaknai suatu tanda yang dilakukan oleh manusia. Definisi yang lebih jelasnya adalah penggunaan tanda (suara/bunyi, gambar, dan lain-lain) untuk menghubungkan, memproduksi, menggambarkan, memotret sesuatu yang dilihat, dibayangkan, dirasakan dalam bentuk fisik tertentu (Danesi, 2012) dalam (Wibowo, 2015). Menurut Judy Giles dan Tim Middleton (1999) (dalam Saum, 2016), representasi berasal dari kata "represent" yang terdiri atas tiga arti, yaitu to stand in for (melambangkan), to speak or act on behalf of (berbicara atas nama seseorang), dan "to re-present" (menghadirkan kembali peristiwa yang sudah terjadi). Representasi memainkan dua peran penting berikuti ini. Pertama, apakah sebuah kelompok, seseorang, gagasan ditampilkan sebagaimana semestinya tanpa diburuk-burukan atau dilebih-lebihkan. Kedua, bagaimana representasi tersebut ditampilkan mulai dari pemilihan kata, kalimat, aksentuasi, foto, yang ditampilkan dalam pemberitaan (Eriyanto, 2011 dalam Saum, 2016).

Sementaraitu, representasimenurutStuart Hall (dalam Aprinta, 2011) mengandung dua pengertian berikut ini. Pertama, representasi mental, yaitu konsep tentang sesuatu yang ada di kepala tiap manusia atau disebut juga sebagai peta konseptual. Representasi mental ini membentuk sesuatu yang abstrak. Kedua, representasi bahasa, yang bahasa berperan penting dalam konstruksi makna. 
Konsep abstrak yang ada dalam kepala manusia harus diterjemahkan dalam bahasa yang lazim supaya dapat menghubungkan konsep-konsep dan ide-ide manusia tentang suatu tanda dan simbol-simbol tertentu. Jadi dapat disimpulkan bahwa representasi adalah cara pandang individu atau kelompok pada suatu fenomena atau kejadian yang ada pada masyarakat. Fenomena yang dikaji dalam penelitian ini terkait perilaku migrasi perempuan dengan tujuan untuk bekerja. Berdasarkan uraian di atas, peneliti mencoba melakukan kajian penelitian yang berjudul "Representasi Perempuan Pekerja Migran menurut Laki-laki di Kota Palembang".

\section{Metode Penelitian}

Penelitian ini menggunakan metode kualitatif. Yang dimaksudkan dengan penelitian menggunakan metode kualitatif adalah metode-metode untuk mengeksplorasi dan memahami makna oleh sejumlah individu atau sekelompok orang dianggap berasal dari masalah sosial atau kemanusiaan (Creswell, 2014). Metode ini digunakan karena peneliti akan mendalami suatu permasalahan yang terjadi di lapangan tanpa melakukan perubahan pada kondisi sosial yang ada di lapangan. Sementara itu, penelitian dilakukan di Kota Palembang dengan mengambil beberapa informan yang telah di pilih secara purposive sampling. Jangka waktu penelitian ini adalah dari September 2017 sampai dengan Desember 2017. Penelitian ini bukan merupakan alat untuk mengeneralisasi, melainkan hanya untuk extrapolation. Hal itu berarti bahwa penelitian hanya dapat digunakan pada kondisi dan tempat yang memiliki persyaratan yang sama dengan keadaan atau karakteristik yang telah diteliti.
Sumber data dalam penelitian ini diperoleh dari informan. Infoman dalam penelitian ini berjumlah 5 laki-laki yang berstatus menikah dan 5 laki-laki yang berstatus belum menikah. Kriteria informan dalam penelitian ini adalah laki-laki berstatus menikah, laki-laki berstatus belum menikah, dan laki-laki yang tinggal di Kota Palembang.

Pengumpulan data pada penelitian ini mengunakan beberapa teknik berikut. Pertama adalah observasi, kedua adalah dengan wawancara, dan ketiga adalah dokumentasi. Analisis data pada penelitian ini dilakukan dengan cara reduksi data, penyajian data, dan penarikan kesimpulan. Kriteria keabsahan data yang digunakan adalah derajat kepercayaan (credibility). Sementara itu, teknik pemeriksaan keabsahan data yang digunakan adalah perpanjangan keikutsertaan, ketekunan pengamatan, dan triangulasi. Hal ini dilakukan untuk menghindari munculnya kesalahan dalam penyajian data oleh peneliti.

\section{Pembahasan}

Informan dalam penelitian ini berjumlah sepuluh orang dan terhadap informan dilakukan wawancara mendalam untuk proses pengumpulan data. Berdasarkan hasil wawancara, ada enam kategori yang dapat dijadikan sebagai representasi perempuan pekerja migran menurut laki-laki di Kota Palembang antara lain. Keenam representasi itu adalah persepsi, peran perempuan pekerja migran dalam rumah tangga, peran suami/pasangan perempuan pekerja migran dalam rumah tangga, fungsi perempuan pekerja migran dalam rumah tangga, gap dan motivasi antara perempuan pekerja dan laki-laki, serta adanya bias gender. Keenam kategori tersebut akan diuraikan dalam bagian pembahasan di bawah ini. 
Persepsi Laki-laki pada Perempuan Pekerja Migran

Semakin tingginya partisipasi perempuan dalam lapangan kerja membuat peran mereka menjadi semakin kompleks. Tidak hanya mengurusi urusan dalam rumah tangga, perempuan masa kini juga terlibat dalam urusan pekerjaan di luar rumah, seperti pekerja kantoran, guru, dosen, pedagang, dan buruh. Tidak sedikit dari perempuan yang, bahkan melakukan migrasi ke daerah yang jauh demi untuk mendapatkan pekerjaan, seperti migrasi antarkabupaten, kota, provinsi, bahkan antarnegara untuk menjadi TKI di luar negeri. Melihat fenomena ini, peneliti melakukan kajian tentang bagaimana persepsi laki-laki di Kota Palembang terhadap perempuan pekerja migran tersebut. Peneliti melakukan wawancara pada beberapa laki-laki yang dijadikan informan penelitian. Sebagai hasilnya, peneliti menemukan beberapa pendapat terkait isu ini.

Pendapat pertama dikemukakan oleh I_ Wy-01 yang berstatus menikah. Menurutnya, dalam era modern sekarang ini bekerja bukan lagi hanya menjadi hak laki-laki. Bekerja merupakan hak perempuan karena sekarang hal itu disebut dengan persamaan gender sehingga antara laki-laki dan perempuan memiliki hak yang sama dalam dunia pekerjaan. Hasil kutipan wawancara dengan I_Wy-01 mengatakan bahwa "Dalam dunia modern bekerja bukan lagi terkait laki-laki atau perempuan. Semua dapat bekerja, artinya terdapat persamaan gender".

Informan di atas telah memahami bahwa antara perempuan dan laki-laki terdapat persamaan gender dalam hal pekerjaan. Berdasarkan jawaban dari informan tersebut, persepsinya terhadap perempuan pekerja migran adalah hal yang wajar dan biasa karena perempuan juga mempunyai hak untuk bekerja. Pendapat yang serupa disampaikan oleh I_Kd-04 status belum menikah. "Perempuan yang bekerja sahsah saja karena mereka juga berhak buat berkarya dan bekerja".

Bagi I_Kd-04, perempuan bekerja adalah hal yang biasa dan dipebolehkan. Menurutnya, bekerja merupakan media perempuan untuk berkarya. Dengan demikian, dapat dikatakan bahwa pendapat laki-laki yang berstatus menikah dan belum menikah memiliki persamaan. Mereka beranggapan bahwa pada zaman modern sekarang ini perempuan bekerja merupakan hal yang biasa terlebih lagi dengan adanya wacana persamaan gender sehingga perempuan juga memiliki hak yang sama dalam lapangan pekerjaan.

Temuan penelitian ini mirip dengan yang dilakukan Djasmoredjo (2004). Penelitiannya menemukan bahwa karyawan laki-laki memiliki persepsi yang baik terhadap pemimpin perempuan. Menurut penelitian Djasmoredjo, pemimpin perempuan memiliki karaktersitik yang istimewa apalagi ketika mereka mampu mengarahkan dan memimpin bawahannya yang adalah laki-laki. Jadi dalam hal ini perempuan bekerja adalah suatu hal yang lumrah apalagi ketika mereka mampu bersifat profesional. Mereka mampu melakukan manajemen waktu yang baik, yaitu antara urusan kantor dan urusan ruamh tangga. Tentunya hal itu tidak terlepas dari adanya dukungan dan komunikasi yang baik dengan suami atau pasangan.

\section{Peran Perempuan Pekerja Migran dalam Rumah Tangga}

Perempuan pekerja migran memiliki waktu yang lebih sedikit untuk mengurus rumah tangga. Hal ini tentunya dapat menjadi permasalahan jika antara suami dan istri tidak terjalin komunikasi dan kerjasama yang baik. 
Oleh karena itu, peneliti membuat pertanyaan dalam penelitian ini terkait dengan peran perempuan yang seharusnya dalam urusan rumah tangga menurut laki-laki di Kota Palembang. Dari hasil wawancara terhadap beberapa informan, maka ditemukan informasi bahwa perempuan pekerja migran harus tetap melakukan pekerjaan rumah tangga dengan baik. Informan mengatakan bahwa perempuan pekerja migran harus tetap sadar dengan tupoksinya sebagai ibu rumah tangga yang berkewajiban mengurus rumah, suami dan anak. Oleh sebab itu, perempuan harus pandai mengatur waktu antara bekerja dan mengurus rumah tangga. Berikut ini kutipan wawancara dengan I_Ir-03 status menikah.

"Perempuan yang bekerja harus dapat mengatur antara bekerja dan mengurus rumah tangga. Jangan sampai pekerjaan yang seharusnya dilakukan oleh istri malah dikerjakan oleh suami, secara norma itu kurang baik."

Informan di atas berpendapat bahwa perempuan pekerja harus tetap menjalankan tugasnya sebagai ibu rumah tangga. la mengatakan bahwa jangan sampai pekerjaan yang seharusnya dikerjakan oleh istri malah dikerjakan oleh suami karena hal tersebut bertentangan dengan norma yang ada di masayarakat. Hal itu sama halnya dengan pendapat yang dikemukan oleh I_Yg-06 status lajang. "Bagi perempuan yang bekerja harus dapat membagi waktu antara bekerja di luar dan di dalam rumah tangga."

Pendapat I_Yg-06 sama dengan pendapat I_Ir-03. I_Yg-06 mengatakan bahwa perempuan pekerja migran selain bekerja juga harus dapat mengatur waktu untuk urusan pekerjaan rumah, serta mengurus anak dan suami. Jadi selain bekerja di luar, perempuan juga harus tetap mengerjakan urusan rumah tangga yang lainnya karena hal itu merupakan kewajibannya sebagai seorang istri atau pun ibu dari anak-anaknya. Perempuan bekerja untuk membantu menambah pendapatan suami yang kurang mencukupi untuk kebutuhan sehari-hari (Soebyakto dan Armansyah, 2016). Temuan penelitian ini serupa dengan penelitian yang dilakukan Salaa (2015). Menurut Salaa, perempuan yang bekerja, selain mereka mampu menambah pendapatan keluarga juga tidak pernah meninggalkan kewajiban mereka sebagai seorang istri, ibu dari anak-anaknya, dan mengurus pekerjaan rumah lainnya. Jadi sebenarnya ketika perempuan bekerja, maka nalurinya sebagai seorang istri dan ibu dari anak-anaknya akan tetap ada. Naluri itu akan diikuti dengan tindakan mereka yang selalu berupaya untuk menunaikan kewajibannya dalam urusan berumah tangga.

\section{Peran Suami/Pasangan Perempuan Pekerja Migran dalam Keluarga}

Sebelum menikah biasanya antara pasangan akan membuat komitmen bersama mengenai hal-hal yang akan dilakukan setelah menikah nantinya. Termasuk di dalamnya adalah urusan istri bekerja atau tidak bekerja dan bagaimana seharusnya tugas dan fungsi masing-masing jika istri atau perempuannya bekerja. Pada penelitian ini, peneliti mencoba mengkaji tentang pandangan kaum laki-laki mengenai perannya di rumah ketika istri atau pasangan mereka bekerja. Hasil penelitian menunjukkan bahwa sebagian besar lakilaki akan dengan senang hati membantu pekerjaan sang istri di rumah atau kalau pun mereka tidak dapat membantu, maka akan mencari alternatif lain misalnya dengan cara menyewa jasa pembantu untuk mengurus urusan rumah tangga. Berikut ini salah satu kutipan hasil wawancaran dengan I_Di-08 
status menikah. "Ketika istri bekerja, maka suami harus membantu mengurus anak dan pekerjaan rumah lainnya."

Menurut I_Di-08, suami harus membantu pekerjaan istri di rumah. Apapun pekerjaan yang dapat dilakukan, maka seharusnya suami ikut membantu. Hal ini bertujuan untuk meringankan beban sang istri karena mereka bekerja juga demi kepentingan keluarga sehingga selayaknya suami di rumah ikut membantu. Suami harus berpikiran positif dan memberikan dukungan kepada istri yang bekerja. Salah satu caranya adalah dengan bergotong royong mengerjakan urusan rumah tangga, seperti mengurus anak, mencuci, dan menyapu. Pendapat yang serupa dikemukan oleh I_Kd-04 status belum menikah.

"Ketika istri bekerja, maka pasangannya harus dapat membantu. Walaupun mungkin tidak terlalu mengerti masalah urusan rumah tangga namun kita dapat mengerjakan apa yang kita bisa atau bersama-sama dengan istri saling membantu."

Menururt I_Kd-04, walaupun laki-laki itu kurang paham dan pandai mengerjakan urusan rumah tangga, ia masih tetap dapat membantu dengan cara mengerjakan apa yang dapat dilakukan atau bergotong royong dengan istri. Misalkan sebelum berangkat kerja mereka bersama-sama mengerjakan urusan rumah tangga, seperti menyapu, menyiapkan makanan, dan memandikan anak. Dengan demikian, dari informasi yang diperoleh sebagian besar laki-laki yang diwawancarai merasa tidak berkebaratan untuk membantu istrinya bekerja di rumah.

Bagi mereka, hal tersebut bertujuan untuk membantu sang istri karena istri bekerja di luar juga demi kepentingan keluarga mereka, seperti untuk menambah pendapatan keluarga demi masa depan anak-anak mereka. Oleh karena itu, wajar saja jika suami atau pasangan mereka ikut membantu pekerjaan rumah yang dapat diselesaikan bersama. Temuan penelitian ini serupa dengan penelitian yang dilakukan Putri dan Sri (2015). Menurut Putri dan Sri, dalam kehidupan berumah tangga, biasanya suami dan istri melakukan kesepakatan bersama dalam tiga hal, yaitu pengambilan keputusan, pengelolaan keuangan, dan pengasuhan anak. Dalam mengambil keputusan, suami akan selalu melibatkan istri untuk membuat keputusan bersama. Pengelolaan keuangan cenderung dipercayakan kepada istri dan pengasuhan anak juga cenderung dilakukan oleh istri, tetapi kadang kala suami terlibat dalam mengurus anak. Hal ini menunjukkan peran suami dalam rumah tangga ketika istri bekerja. Halitu berartisuami harus memberikan kepercayaan dan adanya keterbukaan antara suami istri. Masalah mengurus anak dapat dilakukan secara bersama-sama sehingga dapat saling meringankan tugas masingmasing.

\section{Fungsi Perempuan Pekerja Migran bagi Laki- laki dalam Keluarga}

Perempuan bermigrasi dan bekerja tentunya bukan hanya untuk tujuan kepentingan dirinya sendiri. Apalagi jika yang bermigrasi itu adalah perempuan yang telah menikah. Tentunya ada latar belakang yang kuat sehingga mereka rela bermigrasi demi mencari pekerjaan. Penelitian ini mencoba melakukan kajian tentang persepsi laki-laki di Kota Palembang terkait dengan fungsi perempuan pekerja migran dalam keluarga. Berdasarkan penelitian yang dilakukan ditemukan informasi bahwa fungsi perempuan pekerja migran bagi laki-laki dalam keluarga adalah untuk menambah penghasilan 


\section{Representasi Perempuan Pekerja Migran \\ menurut Laki-laki di Kota Palembang}

keluarga, menambah pendapatan suami, aktualisasi diri, media berkarya bagi perempuan, menambah pengalaman perempuan dan untuk masa depan anak-anak mereka. Berikut ini kutipan hasil wawancara dengan I_Sy-02 status menikah. "Istri bekerja untuk menambah penghasilan keluarga, jika pendapatan suami rendah maka peran suami bekerja akan sangat membantu".

Menurut I_Sy-02, jika istrinya bekerja, maka itu bertujuan untuk menambah penghasilan keluarga. Pendapatan yang diperolehnya sedikit sehingga jika istri bekerja, maka dapat menambah pendapatan suami. Pendapatan yang diperoleh akan digunakan untuk keperluan keluarga selain juga untuk tabungan bagi anak-anak mereka di masa depan. Sama halnya dengan pendapat yang dikemukakan oleh I_Kd-04 status belum menikah.

"Fungsi perempuan bekerja bagi lakilaki selain untuk karir dan karyanya juga dapat dijadikan motivasi bagi lakilaki. Bahwa perempuan dengan segala keterbatasannya dapat bekerja dan munkin gajinya lebih besar dari laki-laki, maka hal itu dapat menjadi motivasi bagi laki-laki untuk lebih semangat bekerja."

Menurut I_Kd-04, perempuan bekerja itu selain menambah pendapatan keluarga juga untuk mengembangkan karier dan karya mereka. Dengan bekerja, perempuan lebih bebas berkarya dan meningkatkan kariernya. Selain itu, perempuan yang bekerja menjadi motivasi bagi laki-laki. Perempuan dengan segala keterbatasan mampu bekerja apalagi laki-laki. Jadi menurut I_Kd-04 melihat perempuan bekerja akan memotivasi laki-laki untuk bekerja lebih baik lagi. Salaa (2015) juga mengungkapkan bahwa tujuan perempuan bekerja tidak lain adalah untuk menambah pendapatan keluarga. Permasalahan yang sering terjadi ketika perempuan bekerja adalah mereka tidak dapat menjalankan perannya sebagai ibu rumah tangga. Untuk mengatasi permasalahan tersebut, menurut Handayani (2013), perlu adanya aturan keterlibatan anggota keluarga dan adanya komunikasi yang baik dengan pasangan mengenai permasalahan kerja dalam keluarga.

Gap dan Motivasi antara Perempuan dan Laki-laki

Perempuan pekerja identik dengan sikap mandiri karena mereka mempunyai penghasilan sendiri. Sebagian laki-laki akan merasa kurang percaya diri mendekati perempuan yang bekerja, apalagi pekerjaan perempuan tersebut lebih baik dan gajinya lebih tinggi daripada laki-laki. Penelitian ini dapat menjawab salah satu permasalahan yang selama ini ada di masyarakat yang mempertanyakan alasan perempuan yang cantik, dengan pekerjaan yang bagus, tetapi terlambat menikah atau tidak menikah. Salah satu penyebabnya menurut hasil penelitian ini adalah karena laki-laki akan merasa minder mendekati perempuan yang bekerja. Hal itu berarti terdapat gap atau batas antara lakilaki dan perempuan yang membuat laki-laki merasa kurang percaya diri untuk mendekati perempuan yang telah bekerja. Berikut ini kutipan hasil wawancara dengan I_Dn-05 status belum menikah. "Saya akan merasa minder mendekati perempuan yang bekerja jika pekerjaannya itu lebih baik daripada saya."

Menurut I_Dn-05, ia akan merasa kurang percaya diri untuk mendekati perempuan yang bekerja. Apalagi jika pekerjaan perempuan tersebut lebih baik daripada pekerjaannya. Pendapat yang serupa dikemukakan oleh I_Yg-06 status lajang. "Saya kurang percaya 
diri untuk mendekati perempuan yang bekerja jika saya belum bekerja jadi terdapat batasan antara laki-laki dan perempuan yang bekerja."

Menurut I_Yg-06, rasa kurang percaya diri akan muncul ketika dia belum bekerja. Laki-laki tidak percaya diri untuk mendekati perempuan yang lebih tinggi karier, pekerjaan, dan pendapatan daripada mereka. Hal ini terjadi karena budaya di Indonesia pada umumnya adalah penganut patriarki sehingga laki-laki merasa belum siap jika posisi perempuan lebih tinggi (Irfarinda, 2014). Ada makna yang unik dari hasil temuan ini. Berdasarkan pendapat di atas, laki-laki tidak akan percaya diri untuk mendekati perempuan yang bekerja lebih tinggi daripada mereka. Oleh karena itu, perempuan yang bekerja lebih sulit mendapatkan pasangan daripada perempuan yang tidak bekerja. Para lelaki juga akan berusaha untuk menyamakan posisi dengan perempuan yang telah bekerja. Mereka berpikir jika ingin mendekati perempuan yang bekerja, maka secara otomatis mereka juga harus memiliki pekerjaan terlebih, bahkan ada yang membuat standar harus memiliki pekerjaan yang lebih baik dari calon pasangannya.

Selanjutnya selain terbentuk gap antara laki-laki dan perempuan. Perempuan pekerja secara otomatis juga menjadi motivasi bagi laki-laki untuk bekerja lebih baik. Berikut ini kutipan hasil wawancara dengan I_Kd04 status belum menikah. "Ketika laki-laki menemukan perempuan yang bekerja munkin itu dapat dianggap sebagai kelebihan dan juga motivasi. Karena perempuan saja dapat bekerja apalagi laki-laki."

Menurut I_Kd-04, ketika menemukan dan melihat perempuan pekerja, ia akan lebih termotivasi untuk memperoleh pekerjaan dan bekerja lebih baik. Pendapat yang serupa disampaikan oleh I_Dn-05 status belum menikah. "Untuk mendekati perempuan yang bekerja setidaknya saya harus memiliki pekerjaan yang lebih baik dari perempuan itu."

Jadi dari beberapa pendapat informan di atas, ketika mereka menemukan perempuan atau pasangan mereka bekerja, laki-laki akan merasa termotivasi. Mereka akan berusaha untuk memperoleh pekerjaan yang lebih atau palingtidak sama dengan perempuan yang ingin mereka dekati. Hal ini tentunya memberikan dampak posistif pada lakilaki, yaitu untuk membangkitkan semangat bekerja lebih baik supaya dapat mendekati dan mendapatkan pasangan yang lebih baik.

\section{Bias Gender}

Gender adalah persamaan hak antara lakilaki dan perempuan yang tidak membedakan jenis kelamin. Hal itu berarti bahwa antara perempuan dan laki-laki sama-sama memiliki kesempatan untuk memperoleh pekerjaan yang baik. Perempuan juga berhak berkarya dan bekerja di luar rutinitasnya sebagai ibu rumah tangga. Berdasarkan hasil penelitian ini, terdapat bias gender dari pernyataan telah disampaikan oleh laki-laki. Masih ada sebagian laki-laki yang merasa bahwa tugas mengurus rumah tangga itu hanyalah kewajiban istri dan apabila dikerjakan oleh suami, maka hal itu bertentangan dengan norma di masyarakat. Selain itu, laki-laki juga tidak mau jika posisi perempuan lebih tinggi darinya, baik dalam hal pekerjaan maupun pendapatan. Hal ini terbukti dari masih ada sebagian laki-laki yang merasa minder dan kurang percaya diri jika pasangan mereka lebih tinggi pekerjaan dan pendapatannya daripada mereka. Berikut ini kutipan hasil wawancara dengan I_Ir-03 status menikah.

"Perempuan yang bekerja harus dapat mengatur antara bekerja dan mengurus rumah tangga. Jangan sampai pekerjaan 
yang seharusnya dilakukan oleh istri malah dikerjakan oleh suami, secara norma itu kurang baik."

Menurut I_Ir-03, pekerjaan rumah adalah kewajiban istri. Jika dikerjakan oleh suami, maka hal itu tidak sesuai dengan norma dan dipandang kurang baik. Oleh sebab itu, perempuan pekerja harus dapat mengatur waktu dengan baik antara bekerja dan mengurus rumah tangga. Selain pembatasan pada pekerjaan rumah, sebagian laki-laki juga membatasi perempuan dalam bermigrasi. Berikut kutipan hasil wawancara dengan I_Yg06 status belum menikah. "Jika perempuan bermigrasi untuk bekerja berstatus lajang maka wajar-wajar saja, namun jika sudah berkeluarga maka hal itu kurang baik."

Menurut I_Yg-06, perempuan boleh melakukan migrasi apabila mereka masih berstatus belum menikah, tetapi apabila telah menikah, maka sebaiknya mereka tidak melakukan migrasi. Perndapat ini serupa dengan pernyataan dari I_Tj-07 status belum menikah. "Perempuan yang bermigrasi untuk bekerja kurang baik karena dapat membuat dia melupakan kewajibannya sebagai ibu rumah tangga."

Berdasarkan pernyataan I_Tj-07, perempuan bermigrasi demi pekerjaan kurang baik jika harus meninggalkan keluarganya. Hal itu dapat membuat perempuan tersebut melalaikan kewajibannya sebagai ibu rumah tangga yang berkewajiban mengurus anak dan suami serta urusan rumah tangga lainnya. Jika harus bermigrasi, maka keluarga perempuan tersebut harus ikut serta bermigrasi. Ada juga sebagian dari laki-laki yang beranggapan bahwa tugas perempuan itu hanyalah di rumah mengurus anak-anaknya, sedangkan bekerja adalah tugas suami.

Temuan penelitian ini sama halnya dengan penelitian yang dilakukan oleh Parry (2017) yang menyatakan bahwa di Afrika Selatan, laki-laki merupakan raja sehingga mereka tidak akan senang jika perempuan memiliki pekerjaan yang lebih baik daripada laki-laki. Perempuan yang bekerja dan tidak dapat mengatur waktu yang baik antara bekerja dan mengurus ruamha tangga sering dijadikan penyebab banyaknya kasus perceraian di Afrika Selatan. Oleh karena itu, selain memahami masalah gender yang baik, diperlukan juga kesadaran terhadap tugas dan fungsi masing-masing antara pasangan suami istri sehingga selain pekerjaan berjalan baik, urusan rumah tangga juga terkendali dan harmonis.

Berdasarkan penelitian ini, maka representasi perempuan pekerja migran menurut laki-laki di Kota Palembang dapat dilihat dari enam kategori, yaitu persepsi, peran perempuan pekerja migran dalam keluarga, peran suami dalam rumah tangga ketika istri bekerja, fungsi perempuan pekerja migran dalam keluarga, gap dan motivasi antara perempuan dan laki-laki, serta bias gender. Dapat disimpulkan secara umum bahwa pandangan mayoritas laki-laki yang dijadikan informan terhadap perempuan pekerja migran positif. Bagi laki-laki, perempuan yang bermigrasi untuk tujuan bekerja merupakan fenomena yang wajar di zaman modern sekarang ini. Ketika perempuan telah memiliki pendidikan yang baik, maka sebaiknya jika mereka bekerja sebagai bentuk penghargaan atas pendidikan yang telah mereka capai. Sementara itu, perempuan pekerja harus dapat melakukan manajemen waktu yang baik antara bekerja di kantor dengan mengurus rumah tangga. Perempuan pekerja harus tetap menjalankan kewajibannya sebagai istri dan ibu dari anakanaknya. Perempuan harus secara sadar mengerjakan tugas-tugasnya sebagai ibu rumah tangga. 
Komunikasi yang baik dengan pasangan terkait masalah pekerjaan di dalam rumah harus didiskusikan secara baik sehingga tidak menimbulkan permasalahan di kemudian hari. Sebaiknya perempuan bekerja di lingkungan yang dekat dengan keluarga dan jika harus bermigrasi, maka keluarga harus ikut serta atau memilih untuk menjadi ibu rumah tangga saja. Perempuan yang bekerja akan membuat rasa percaya diri laki-laki yang ingin mendekati mereka sedikit rendah. Laki-laki yang memiliki pekerjaan yang lebih rendah daripada mereka akan cenderung untuk menghindar dari perempuan yang telah bekerja.

\section{Kesimpulan}

Penelitian tentang representasi perempuan pekerja migran menurut laki-laki di Kota Palembang menemukan bahwa terdapat berbagai pandangan atau persepsi laki-laki di Kota Palembang baik yang berstatus menikah ataupun belum menikah. Hasil penelitian menunjukkan bahwa sebagian besar dari informan laki-laki yang diwawancarai memiliki persepsi yang baik terhadap perempuan pekerja migran. Perempuan pekerja migran adalah hal yang baik dan biasa dalam era modern. Hanya saja ketika bermigrasi hendaknya perempuan memikirkan urusan pekerjaan rumah tanggannya. Hendaknya perempuan bekerja di tempat yang dekat dengan lingkungan keluarganya dan jika harus bermigrasi, maka keluarga harus ikut serta.

Perempuan pekerja migran selain bekerja harus dapat menunaikan kewajibannya secara sadar sebagai ibu rumah tangga yang bertugas mengurus rumah, suami, dan anak. Sebagian besar informan laki-laki dalam penelitian ini tidak merasa keberatan untuk membantu pekerjaan rumah ketika istri bekerja. Sebagian informan mengatakan hal tersebut merupakan sesuatu yang wajar karena istri bekerja juga untuk membantu kebutuhan keluarga. Perempuan pekerja migran memberikan gap dan motivasi bagi laki-laki. Laki-laki merasa kurang percaya diri mendekati perempuan yang bekerja. Apalagi pekerjaan perempuan tersebut lebih baik daripada laki-laki. Namun, di samping itu perempuan yang bekerja memberikan motivasi bagi para lelaki untuk bekerja lebih baik sehingga mereka dapat mencapai posisi yang lebih atau paling tidak setara dengan perempuan yang bekerja tersebut.

Penelitian ini juga menemukan bias gender dari persepsi laki-laki terhadap perempuan yang bekerja. Masih ada laki-laki yang beranggapan bahwa tugas perempuan hanya mengurus anak di rumah, pekerjaan rumah adalah kewajiban istri, serta perempuan harusnya tidak melakukan migrasi dan bekerja pada jarak yang dekat dengan lingkungan keluarga. Sebagian laki-laki juga tidak merasa percaya diri ketika ada perempuan yang memiliki pekerjaan yang lebih baik daripada mereka. Temuan yang menarik dari penelitian ini adalah laki-laki membuat kriteria tersendiri bagi kaum perempuan pekerja. Kriteria yang dimaksud adalah dalam hal perihal pasangan. Bagi laki-laki yang akan mendekati perempuan yang bekerja, mereka harus memiliki pekerjaan yang lebih atau paling tidak sama dengan perempuan yang akan didekatinya itu. Temuan lainnya menunjukkan penyebab perempuan yang bekerja lebih sulit mendapatkan pasangan adalah karena laki-laki kurang percaya diri untuk mendekati perempuan yang bekerja apalagi ketika mereka telah memiliki jabatan dan pendapatan yang lebih besar daripada laki-laki. 


\section{Saran}

Perempuan pekerja harus dapat melakukan manajemen waktu yang baik antara bekerja di luar dan di dalam rumah. Pembagian kerja antara suami dan istri dalam urusan rumah tangga harus dikomunikasikan dengan baik sebelum menikah dan setelah menikah untuk menghindari kesalahpahaman. Perempuan harus dapat menyakinkan suami bahwa ketika karir dan pendapatannya lebih tinggi daripada suami, maka hal itu bukan berarti untuk menyaingi suami atau merendahkannya. Namun, semua itu semata-mata untuk kepentingan keluarga dan masa depan anakanak mereka.

Keterbatasan penelitian ini adalah pada variasi laki-laki yang dijadikan informan. Karena keterbatasan waktu dan dana maka karaktersitik informan dalam penelitian ini hanya dibatasi pada status, dan tempat tinggal. Seharusnya ada lebih banyak karakteristik yang dapat mewakili untuk memperoleh jawaban dan informasi yang lebih mendalam. Karakteristik yang perlu ditambah adalah, seperti dari tingkat pendidikan, umur, dan pekerjaan. Saran untuk peneliti selanjutnya adalah supaya dapat dibuat kajian tentang persepsi laki-laki terhadap perempuan pekerja migran dengan karakteristik yang lebih bervariasi. Selain irtu juga perlu dilakukan survei dalam bentuk angket tentang pernyataan setuju dan tidak setuju dengan perempuan pekerja migran.

\section{Daftar Pustaka}

Aprinta, Gita. 2011. Kajian Media Massa: Representasi Girl Power Wanikta Modern dalam Media Online (Studi Framing Girl Power dalam Rubrik Karir dan Keuangan Femina Online). The Mesenger, Volume II, Nomor 2, Edisi Januari.
Armansyah \& Kiki Aryaningrum. (2017). Analisis Karakteristik Demografi Pekerja Wanita Sektor Informal pada Era Masyarakat Ekonomi ASEAN di Kota Palembang. Populasi, 25(1), 52-63. Retrieved from https://jurnal.ugm.ac.id/ populasi/article/view/32415/19530.

Soebyakto, Bambang Bemby; Armansyah. 2016. "Migran Women Working at Informal Sectors: Empirical Study in Kuto Batu Village, Ilir Timur II Palembang City". International Journal of Humanities and Social Science, Vol. 6, No. 4; April.

BPS Kota Palembang. 2014. Palembang dalam Angka. Palembang.

Creswell, John, W. 2014. Research Design: Pendekatan Metode Kualitatif, Kuantitatif, dan Campuran. Yogyakarta: Pustaka Pelajar.

Djasmoredjo, Bene, D.M. 2004. "Persepsi Karyawan Laki-laki Terhadap Pemimpin Perempuan:Apakah Pemimpin Perempuan Lebih Bersifat Asuh daripada Pemimpin Laki-laki". Jurnal Widya Manajemen \& Akuntansi. Vol 4, No.3, Desember 2004. https://media.neliti.com/media/ publications/222153-persepsi-karyawanlaki-laki-terhadap-pem.pdf. Diakses 12 Januari 2018. Pukul 22:06 WIB.

Handayani, Arri. 2013. Keseimbangan Kerja Keluarga pada Perempuan Bekerja: Tinjauan Teori Border. Buletin Psikologi, Vol. 21, No. 2, Desember 2013, HIm. 90-101. https://journal.ugm.ac.id/buletinpsikologi/ article/download/7373/5740. Diakses 13 Januari 2018, Pukul 13:46 WIB.

Irfarinda, Mutiara. 2014. "Analisis Gender Tenaga Kerja Wanita dalam Partisipasi Ekonomi Rumah Tangga". Laporan Studi Pustaka. http://www.skpm.ipb.ac.id/ karyailmiah/index.php/studipustaka/article/ downloadSuppFile/1430/764. Diakses 13 Januari 2018. Pukul 14:00 WIB. 
Nasution, Arif. 1999. Globalisasi dan Migrasi Antar Negara. Medan: Alumni.

Parry, Bianca Rochelle dan; Puleng Segalo. 2017. "Eating Burnt Toast: The Lived Experiences of Female Breadwinners in South Africa". Jounal of International Women's studies Vol. 18, No. 4, August 2017.

Putri, Dyah Purbasari Kusumaning dan; Sri Lestari. 2015. "Pembagian Peran dalam Rumah Tangga pada Pasangan Suami Istri Jawa". Jurnal Penelitian Humaniora, Vol. 16, No. 1, Februari 2015. Hal. 72-85. http:// journals.ums.ac.id/index.php/humaniora/ article/view/1523/1056. Diakses 13 Januari 2018. Pukul 13:25 WIB.

Salaa, Jeiske. 2015. Peran Ganda Ibu Rumah Tangga dalam Meningkatkan Ekonomi Keluarga di Desa Tarohan Kecamatan Beo Kabupaten Kepulauan Talaud. Jurnal Holistik Tahun VIII No. 15 Januari-Juni $2015 . \quad$ https://media.neliti.com/media/ publications/959-ID-peran-ganda-iburumah-tangga-dalam-meningkatkanekonomi-keluarga-di-desa-tarohan.pdf. Diakses 13 Januari 2018. Pukul 13:06 WIB. Saum, Tiara. 2016. Wanita dalam Surat Kabar (Representasi Wanita Karier dalam Rubrik Persona Harian Kompas Edisi Januari Februari 2016). Surakarta: Program Studi IImu Komunikasi Fakultas IImu Sosial dan Politik Universitas Sebelas Maret.

Standing, Guy. 1991. Konsep-Konsep Mobilitas di Negera Sedang Berkembang. Yogyakarta: Pusat Penelitian Kependudukan UGM.

Tarmizi, Nurlina. 2013. Tri Matra Kependudukan. Palembang: Unsri Press. Wibowo, Eviyono Adi. 2015. Representasi Perempuan dalam Film Wanita Tetap Wanita (Analisis Semiotika Representasi Perempuan dalam Fil Wanita Tetap Wanita). Surakarta: Program Studi IImu
Komunikasi Fakultas Komunikasi dan Informatika Universitas Muhammadiyah Surakarta.

http://randyibo.blogspot.co.id/2016_01_01_ archive.html diakses 3 Oktober 2016, pukul 17.28 WIB

http://www.komnasperempuan.go.id/ wpcontent/uploads/2016/03/KOMNASPEREMPUAN-_-CATATAN-TAHUNAN2016edisi-Launching-7-Maret-2016.pdf diakses 03 Oktober 2016, pukul 18.28. WIB.

http://dinkes.palembang.go.id/tampung/ dokumen/dokumen-147-263.pdf diakses, 3 Oktober 2016, Pukul 19.39 WIB.

http://journals.ums.ac.id/index.php/JEP/ article/viewFile/810/536, diakses 03 Oktober 2016, Pukul 19.43 WIB.

https://ugm.ac.id/id/berita/2649migrasi. perempuan.mendorong. perubahan.nilai. budaya. 